\title{
Brain-Derived Neurotrophic Factor (BDNF) Induces Dendritic Targeting of BDNF and Tyrosine Kinase B mRNAs in Hippocampal Neurons through a Phosphatidylinositol-3 Kinase-Dependent Pathway
}

\author{
Massimo Righi, ${ }^{1}$ Enrico Tongiorgi,, ${ }^{1,2}$ and Antonino Cattaneo ${ }^{1}$ \\ 1/nternational School for Advanced Studies (ISAS/SISSA), Neuroscience Program, 34014 Trieste, Italy, and ${ }^{2 B R A I N}$ \\ Centre for Neuroscience, Department of Biology, University of Trieste, 34127 Trieste, Italy
}

This study aims to understand the mechanisms of dendritic targeting of brain-derived neurotrophic factor (BDNF) and tyrosine kinase $B$ (TrkB) mRNAs. We show that brief depolarizations are sufficient to induce accumulation of BDNF and TrkB mRNAs in dendrites of hippocampal neurons. Endogenous BDNF, secreted during the $\mathrm{KCl}$ stimulation, contributes significantly to the dendritic accumulation of BDNF-TrkB mRNAs. In the absence of depolarization, $1 \mathrm{~min}$ pulses of exogenous BDNF are sufficient to induce dendritic accumulation of BDNF-

Neurons are highly polarized cells and require mechanisms to modulate protein function and activity locally, also in relation to synaptic and electrical activity. The localization of specific mRNAs in dendrites has been proposed to contribute to these mechanisms (Steward, 1997; Tiedge et al., 1999). According to this view, long-term synaptic changes would be regulated by the delivery of selected mRNAs to postsynaptic dendritic sites. This is postulated to contribute to the local synthesis of the corresponding protein in activated dendrites (Torre and Steward, 1992; Crino and Eberwine, 1996). For some mRNAs, the dendritic localization is linked to the electrical activity of neurons (Tongiorgi et al., 1997; Roberts et al., 1998; Steward et al., 1998). We have previously reported that the mRNAs for brain-derived neurotrophic factor (BDNF) and tyrosine kinase B (TrkB) are detectable in the dendrites of hippocampal neurons in culture (Tongiorgi et al., 1997). Studies of BDNF mRNA in vivo indicate that under most circumstances the mRNA appears to be localized exclusively in the region of the cell body (Lauterborn et al., 1996; Schmidt-Kastner et al., 1996). In culture, the dendritic localization of these mRNAs is greatly enhanced by depolarizing stimuli and contributes to the local synthesis of the corresponding proteins in the dendritic compartment (Tongiorgi et al., 1997). We have recently found that BDNF mRNA can be detected in dendrites in vivo under certain circumstances, for example when it is induced by pilocarpine seizures (Tongiorgi et al., 1999).

In hippocampal neurons, depolarizing stimuli increase both the

\footnotetext{
Received Aug. 30, 1999; revised Feb. 18, 2000; accepted Feb. 24, 2000.

This work was supported by a joint grant from Ministero dell'Universitá e della Ricerca Scientifica e Tecnologica and ISAS/SISSA (Cofinanziamento 97). We are grateful to Dr. Fabio Mammano for performing the electrophysiological recordings, to Sonia Covaceuszac and Elisa Margotti for purification of the TrkB immunoadhesins, to Mara Armellin for technical help, and to Dr. Kevin Ainger and Prof. Andrea Nistri for helpful suggestions and critical reading of this manuscript. We also thank Amgen (Thousand Oaks, CA) for providing anti-BDNF antibody.

Correspondence should be addressed Dr. Antonino Cattaneo, International School for Advanced Studies (SISSA), Neuroscience Program, Via Beirut 2/4-34014 Trieste, Italy. E-mail: cattaneo@sissa.it.

Copyright (C) 2000 Society for Neuroscience $\quad 0270-6474 / 00 / 203165-10 \$ 15.00 / 0$
}

TrkB mRNAs. After binding to TrkB, BDNF exerts this action by activating a PI-3 kinase-dependent pathway. The accumulation of dendritic mRNA by BDNF is not mediated by BDNF-induced neurotransmitter release. Because most hippocampal neurons coexpress BDNF and TrkB receptors, these results show that the subcellular distribution of BDNF-TrkB mRNAs is under the control of an autocrine-paracrine BDNF-TrkB-dependent loop.

Key words: dendritic mRNA; BDNF; TrkB; neurotrophins; $P$ /3 kinase; intracellular pathway transcription (Zafra et al., 1990, 1992) and the dendritic transport (Tongiorgi et al., 1997) of BDNF mRNAs. Moreover, BDNF is rapidly accumulated in the dendrites (Tongiorgi et al., 1997) and released (Goodman et al., 1996) in an activity-dependent way. Previous studies have demonstrated a tight link of the BDNFTrkB signaling system with the long-term modulation of synaptic efficacy (for review, see Thoenen, 1995; Schuman, 1997, 1999). In particular, BDNF can increase synaptic transmission and has been implicated in hippocampal long-term potentiation (LTP) (Korte et al., 1995, 1996; Patterson et al., 1996; Kang et al., 1997). Furthermore, BDNF enhances synaptic transmission in the rat hippocampus, a process that requires local protein synthesis in the postsynaptic dendrites (Kang and Schuman, 1996). One neurotrophin (NT-3) has been shown to regulate the content of a yet unidentified pool of mRNAs in dendrites (Knowles and Kosik, 1997). The possibility that neurotrophins can regulate the dendritic content of selected mRNAs, possibly including their own mRNAs, is intriguing.

It is therefore of primary interest to provide a more detailed description of the mechanisms involved in the redistribution of neurotrophin mRNA in hippocampal neurons after depolarization or other stimuli. In this paper we demonstrate that endogenous BDNF, released from the neurons during the depolarizing stimulus and acting through $\mathrm{TrkB}$ receptors, makes a significant contribution to the dendritic accumulation of BDNF and TrkB mRNAs. Moreover, BDNF can induce the dendritic targeting of these mRNAs, in the absence of a concomitant $\mathrm{KCl}$ stimulation, by an intracellular signaling mechanisms involving PI-3 kinase.

\section{MATERIALS AND METHODS}

Cell cultures. Primary hippocampal neurons were made according to the method of Malgaroli and Tsien (1992), with slight modifications (Tongiorgi et al., 1997). Hippocampi were dissected from 1- to 4-d-old animals. All the dissection was performed in $200 \mu \mathrm{M}$ kynurenic acid (Sigma, St. Louis, MO) and $25 \mu \mathrm{M}$ 2-amino-5-phosphonovalerate (APV) (Tocris Cookson, Bristol, UK) on ice. Cells were cultured for $8 \mathrm{~d}$ in 5\% $\mathrm{CO}_{2}$-humidified incubator, in minimum essential medium with Earle's 
salts and Glutamax I (Life Technologies, Gaithersburg, MD), with 5-10\% fetal bovine serum, $7 \mathrm{mg} / \mathrm{ml} \mathrm{D-glucose,} 3.6 \mathrm{mg} / \mathrm{ml}$ HEPES, 0.1 $\mu \mathrm{g} / \mathrm{ml}$ biotin, $1.5 \mu \mathrm{g} / \mathrm{ml}$ vitamin B12, $30 \mu \mathrm{g} / \mathrm{ml}$ insulin, and $100 \mu \mathrm{g} / \mathrm{ml}$ bovine transferrin. Proliferation of non-neural cells was prevented by $2.5-5 \mu \mathrm{M}$ cytosine $\beta$-D-arabinof uranoside from the second day in culture onwards.

Electrophysiology. Whole-cell recordings were performed at room temperature (RT) on hippocampal neurons cultured for 8-12 d with a patch-clamp amplifier (EPC7; List Biologic, Campbell, CA). Patch pipettes were filled with a solution containing (in $\mathrm{mM}$ ): $120 \mathrm{~K}$-gluconate, 4 $\mathrm{MgCl}_{2}, 0.6$ EGTA, $2 \mathrm{Na}_{2}$-ATP, $0.2 \mathrm{Na}_{2}$-GTP, and 49 HEPES, adjusted to $\mathrm{pH} 7.4$ and $300 \mathrm{mOsm}$ with D-glucose. Cells were continuously perfused in a solution containing (in $\mathrm{mM}$ ): $5 \mathrm{KCl}, 130 \mathrm{NaCl}, 4 \mathrm{MgCl}_{2}, 2$ $\mathrm{CaCl}_{2}, 30$ D-glucose, 0.001 glycine, and 25 HEPES, pH 7.4. Patch-clamp experiments on hippocampal neurons were performed, on the same cell, in control condition and after bath application of $20 \mathrm{ng} / \mathrm{ml}$ BDNF.

Preparation of TrkB immunoadhesin. Soluble TrkB receptors were engineered as immunoadhesins (Chamow and Ashkenazi, 1996) and were produced by linking the extracellular domain of the human TrkB receptor to the Fc portion of camel $\mathrm{Ig} \operatorname{IgG} 2$, constituted of a long hinge (35 amino acid residues), followed by the $\mathrm{C}_{\mathrm{H}} 2$ and $\mathrm{C}_{\mathrm{H}} 3$ domains (Hamers-Casterman et al., 1993). The resulting DNA sequence coding for human TrkB immunoadhesin was inserted in Baculovirus (bv) genome [Autographa californica nuclear polyhedrosis virus (AcNPV)], using pAcGP67B transfer vector for amplification of virus in Sf9 insect cells. For expression, H5 insect cells were infected with amplified recombinant bv, and immunoadhesins were purified from cell culture medium by affinity chromatography on a Protein A-Sepharose column. Sf9 cells were cultured in trichoplusia N1 medium-formulation HINK medium with $10 \%$ fetal calf serum, whereas H5 cells were cultured in Ex-Cell 400 medium, both at $27^{\circ} \mathrm{C}$.

$K C l$ and BDNF stimulation of cultured hippocampal neurons. For in situ hybridization experiments, cells were depolarized for the indicated times at $37^{\circ} \mathrm{C}$, with $10 \mathrm{~mm} \mathrm{KCl}$ solution $(\mathrm{K})$ prepared as previously described (Tongiorgi et al., 1997). For in situ hybridization and immunocytochemistry experiments, hippocampal neurons were incubated for the indicated times at $37^{\circ} \mathrm{C}$ with $20 \mathrm{ng} / \mathrm{ml}$ BDNF. For the experiments with BDNF ligands, cells were incubated for the indicated times at $37^{\circ} \mathrm{C}$ with $10 \mathrm{~mm}$ $\mathrm{KCl}$ or $20 \mathrm{ng} / \mathrm{ml} \mathrm{BDNF}$ in the presence of TrkB-IgG $(3 \mu \mathrm{g} / \mathrm{ml})$, a nonblocking rabbit anti-BDNF antibody $(3 \mu \mathrm{g} / \mathrm{ml}$; Ab-1; Chemicon, Temecula, CA) and a blocking rabbit anti-BDNF antibody $(3 \mu \mathrm{g} / \mathrm{ml}$; Ab-2; Amgen, Thousand Oaks, CA; Yan et al., 1997). For pharmacological experiments, cells were preincubated for $45 \mathrm{~min}$ at $37^{\circ} \mathrm{C}$ with the drugs before starting the incubation in high potassium or with BDNF. Final drug concentrations were $30 \mathrm{~nm}$ K252a (Calbiochem, La Jolla, CA), $100 \mathrm{~nm}$ wortmannin (Calbiochem), $10 \mu \mathrm{M} \mathrm{KN}-62$ (Calbiochem), 50 $\mu \mathrm{M}$ PD-098059, (Calbiochem), $100 \mu \mathrm{M}$ picrotoxin (Sigma), $10 \mu \mathrm{M}$ CGP 35348 (CIBA-Geigy, Basel, Switzerland), $20 \mu \mathrm{M}$ CNQX, (Tocris), $25 \mu \mathrm{M}$ APV (Tocris), and $0.5 \mu \mathrm{M}$ tetrodotoxin (TTX; Tocris).

Bioassays on PC12 cell. Rat PC12 pheochromocytoma cells (Greene and Tischler, 1976) were maintained in Roswell Park Memorial Institute (RPMI) 1640 medium (Life Technologies), supplemented with 5\% fetal calf serum and $10 \%$ heat-inactivated horse serum. For survival and differentiation experiments, PC12 cells were washed with serum-free medium and plated in collagen-coated $35 \mathrm{~mm}$ Petri dishes at a density of $4 \times 10^{5}$ cells per dish in RPMI medium supplemented with $1 \%$ horse serum (1\% HS). PC12 cells were cultured for 1 week in $5 \% \mathrm{CO}_{2^{-}}$ humidified incubator. Negative control cells were cultured in $1 \% \mathrm{HS}$, on the contrary, positive control cells were cultured in $1 \% \mathrm{HS}$ with $20 \mathrm{ng} / \mathrm{ml}$ nerve growth factor (NGF). Drug-treated cells were incubated in $1 \% \mathrm{HS}$ with $20 \mathrm{ng} / \mathrm{ml} \mathrm{NGF}$ and $30 \mathrm{nM} \mathrm{K} 252 \mathrm{a}, 50 \mu \mathrm{M}$ PD-098059, $100 \mathrm{nM}$ wortmannin, or $10 \mu \mathrm{M} \mathrm{KN}-62$ for 1 week. In all cases fresh medium were replaced every 2 d. In PC12 cells the KN-62 and wortmannin drugs did not block NGF differentiation as described (Kimura et al., 1994; Solem et al., 1995).

In situ hybridization on cultured hippocampal neurons. The rat BDNF cDNA pBCDPst (nucleotides 74-525; Maisonpierre et al., 1991) was kindly provided by Dr. A. Negro (Fidia Research Laboratory, Padova, Italy). The rat TrkB cDNA clone was kindly provided by Dr. Y Bozzi (Institute of Neurophysiology, Consiglio Nazionale delle Ricerche, Pisa, Italy) (Bozzi et al., 1995), and contained the first 238 bp of the region coding for the tyrosine kinase domain (nucleotides 2163-2401; Middlemas et al., 1991). The mouse GAP43 cDNA was kindly provided by Dr. P. Caroni (Friedrich Miescher Institute, Basel, Switzerland) (Aigner et al., 1995). After linearization of the plasmids, the digoxigenin (DIG)- labeled riboprobes were synthesized with a SP6/T7 DIG RNA labeling kit (Boehringer Mannheim, Mannheim, Germany) according to the manufacturer's instructions. For in situ hybridization, cells were fixed 10 min at RT in $4 \%$ paraformaldehyde in PBS, washed in PBS, and permeabilized in ethanol absolute for $15 \mathrm{~min}$ at $-20^{\circ} \mathrm{C}$. After rehydration, cells were prehybridized at $55^{\circ} \mathrm{C}$ for $90 \mathrm{~min}$ in the hybridization mix containing: 20 mM Tris-HCl, pH 7.5, 1 mm EDTA, $1 \times$ Denhardt's solution, 300 $\mathrm{mM} \mathrm{NaCl}, 100 \mathrm{~mm}$ dithiothreitol, $0.5 \mathrm{mg} / \mathrm{ml}$ salmon sperm DNA, 0.5 $\mathrm{mg} / \mathrm{ml}$ polyadenylic acid, and $50 \%$ formamide. In situ hybridization was performed overnight at $55^{\circ} \mathrm{C}$ in the hybridization mix with $10 \%$ dextrane sulfate and the riboprobes $(50-100 \mathrm{ng} / \mathrm{ml})$. High-stringency washes were performed in $0.1 \%$ SSC $-0.1 \%$ Tween 20 at $60^{\circ} \mathrm{C}$. Cells hybridized with digoxigenin-labeled riboprobes were incubated overnight at $4^{\circ} \mathrm{C}$ with anti-DIG Fab fragments coupled to alkaline phosphatase (Boehringer Mannheim), diluted 1:500 in 10\% fetal calf serum in PBS $+0.1 \%$ Tween 20 (PBST). After washes in PBST, in situ stainings were developed for 16 $\mathrm{hr}$ at $4^{\circ} \mathrm{C}$ with 4-nitroblue tetrazolium and 5-bromo-4-chloro-3-indolylphosphate in $100 \mathrm{~mm}$ Tris- $\mathrm{HCl}$, $\mathrm{pH} 9.5,50 \mathrm{~mm} \mathrm{MgCl}_{2}, 100 \mathrm{~mm} \mathrm{NaCl}$, and $1 \mathrm{~mm}$ Levamisol.

Antibody staining of cultured hippocampal neurons. Fixation and permeabilization of hippocampal neurons was performed with the same in situ hybridization procedure described above. After permeabilization, cells were incubated for $3 \mathrm{hr}$ at RT with: (1) rabbit anti-zif antibody (Egr-1; Santa Cruz Biotechnology, Santa Cruz, CA) diluted 1:1000 in $10 \%$ fetal calf serum in PBST, or (2) rabbit anti-c-fos antibody (Calbiochem) diluted 1:1000 in 10\% fetal calf serum in PBST. After washes in PBST, cells were incubated $1 \mathrm{hr}$ at RT with biotinylated anti-rabbit IgG antibody (1:100 in 10\% fetal calf serum in PBST; Vector Laboratories, Burlingame, CA), followed by $30 \mathrm{~min}$ incubation at RT with the horseradish peroxidase-coupled Vectastain ABC kit (Vector Laboratories). After washes in PBST, neurons were reacted with $0.05 \%$ diaminobenzidine tetrahydrochloride, $0.25 \%$ nickel ammonium sulfate, $0.25 \%$ glucose, and $0.01 \% \mathrm{H}_{2} \mathrm{O}_{2}$ in PBS at RT. Finally, cells were washed in PBS and mounted in $90 \%$ glycerol in PBS. Staining was analyzed with a Zeiss Axiophot microscope.

Quantitative imaging analysis and statistics. Nonradioactive in situ hybridization was analyzed by viewing stained cultures under bright-field illumination with a Zeiss Axiovert 10 microscope with a differential interference contrast-equipped lens $(20 \times$ magnification). Stained neurons were acquired with a charge-coupled device (CCD) camera (3CCD camera; Dage-MTI, Michigan City, IN) and digitized with the image analysis program Optimas version 6.1. The function "draw line" was used to measure, starting from the base of the dendrites, the maximal distance of dendritic labeling (MDDL) as previously described (Tongiorgi et al., 1997). Dendrites were traced, in a conservative manner, up to the point at which the in situ labeling was clearly distinguishable from the background. The background level obtained in sister cell cultures hybridized with the sense probes was used as a reference to distinguish the actual labeling obtained with the antisense probes from the background. The number of dendrites measured is between 100 and 300 for each set of experiments (at least three independent experiments). The individual preparations were coded and analyzed in a blind manner. The data of the MDDL were normalized by dividing each single measurement obtained in the different experimental conditions by the mean of the controls and were statistically analyzed with Kruskal-Wallis one-way ANOVA on ranks, followed by a multiple comparison procedure with Dunn's method.

\section{RESULTS}

\section{The dendritic localization of BDNF and TrkB mRNAs is regulated by the duration of depolarization}

We have previously demonstrated that sustained depolarization of hippocampal neurons in culture, by increasing the extracellular $\mathrm{KCl}$ concentration from 3.5 to $10 \mathrm{~mm}$ for $3 \mathrm{hr}$, induces an increase in the extent of dendritic localization for BDNF-TrkB mRNAs (Tongiorgi et al., 1997). The same study has also shown that in cultures depolarized for $30 \mathrm{~min}$ only, there is no significant increase in the dendritic localization. Dendritic accumulation of these mRNAs, therefore, requires a longer time to develop. This latency could be related to the induction phase of this phenomenon or to the dendritic targeting process itself. To distinguish between these two possibilities, hippocampal neurons in culture 
A

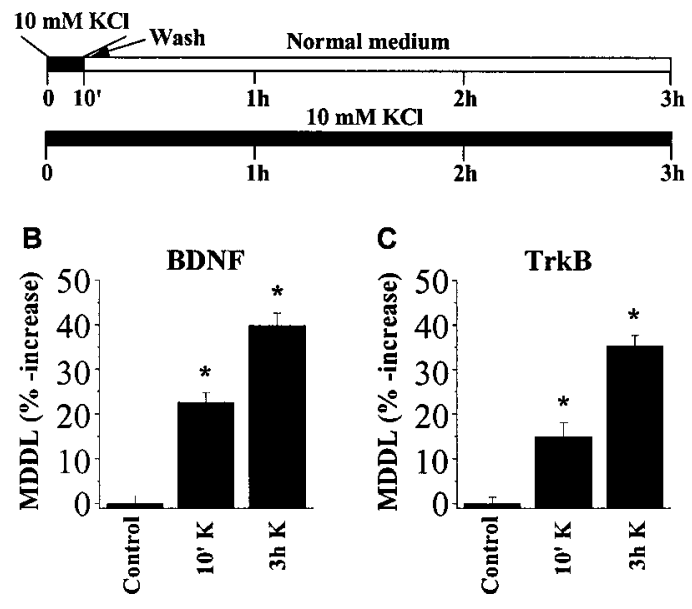

Figure 1. Quantification of the MDDL at various times of incubation in $10 \mathrm{mM} \mathrm{KCl}$. $A$, Hippocampal neurons were incubated with $10 \mathrm{mM} \mathrm{KCl}$ for $3 \mathrm{hr}$ continuously or for only $10 \mathrm{~min}$, followed by an incubation in control medium for $2 \mathrm{hr}$ and $50 \mathrm{~min}$. Bars in $B$ and $C$ indicate the percentage-fold increase of the mean MDDL with respect to the controls. Error bars represent SE. $B$, BDNF mRNA. The average MDDL in control condition is $30.2 \mu \mathrm{m}$. Depolarization with $10 \mathrm{~mm} \mathrm{KCl}$ for either $10 \mathrm{~min}\left(10^{\prime} \mathrm{K}\right)$ or $3 \mathrm{hr}(3 h \mathrm{~K})$ increases the MDDL at $3 \mathrm{hr}(22$ and $39 \%$ increase, respectively). $C$, TrkB mRNA. The average MDDL in control condition is 32.3 $\mu \mathrm{m}$. Depolarization with $10 \mathrm{~mm} \mathrm{KCl}$ for either $10 \mathrm{~min}\left(10^{\prime} \mathrm{K}\right)$ or $3 \mathrm{hr}(3 \mathrm{~h}$ $K)$ increases the MDDL at $3 \mathrm{hr}(15$ and $35 \%$ increase, respectively). *Significantly different with respect to the control $(p \leq 0.001)$.

were incubated with $10 \mathrm{~mm} \mathrm{KCl}$ for either $3 \mathrm{hr}$ or for $10 \mathrm{~min}$ only, followed by control solution up to $3 \mathrm{hr}$ (Fig. $1 \mathrm{~A}$ ), to maintain the same incubation time. The subcellular localization of the mRNA for BDNF and its receptor TrkB was determined by nonradioactive in situ hybridization in rat hippocampal neurons $(8 \mathrm{~d}$ in culture). The increased dendritic localization of these mRNAs was quantified by determining the MDDL in a given culture condition (see Materials and Methods). For these measurements, cells with a well identified dendritic tree were randomly chosen within the cell population. All type of dendrites (apical, basal, thin, or large) were measured, and therefore the average MDDL was calculated on a very heterogeneous population of dendrites.

In control conditions, mRNAs for both BDNF or TrkB was localized to the somatodendritic compartment. For this set of experiments the average MDDL in control condition was $30.2 \mu \mathrm{m}$ for BDNF mRNA and $32.3 \mu \mathrm{m}$ for TrkB mRNA. As previously reported (Tongiorgi et al., 1997), after depolarization with $10 \mathrm{mM}$ $\mathrm{KCl}$ for $3 \mathrm{hr}$, an increase in the extent of dendritic localization for both BDNF and TrkB mRNAs was observed (Fig. 1B,C). Interestingly, also a much shorter depolarization induced a significant increase in MDDL, provided that the cells were observed after 3 hr. For both BDNF and TrkB there was a progressive MDDL increase from $10 \mathrm{~min}$ depolarization to $3 \mathrm{hr}$ of continuous depolarization. For BDNF mRNA the increase in MDDL measured after the $10 \mathrm{~min}$ depolarization protocol was 22\% (MDDL, 37 $\mu \mathrm{m})$, whereas the increase in dendritic localization observed after $3 \mathrm{hr}$ of continuous incubation with $10 \mathrm{~mm} \mathrm{KCl}$ was 39\% (MDDL, $42.3 \mu \mathrm{m})$ (Fig. 1B). Similar results were obtained with TrkB mRNA, with a 15\% (MDDL, $37.1 \mu \mathrm{m})$ and a 35\% (MDDL, 43.7 $\mu \mathrm{m}$ ) increase of MDDL after depolarization for $10 \mathrm{~min}$ and $3 \mathrm{hr}$, respectively (Fig. $1 C$ ).

In conclusion, we showed that short depolarization times were sufficient to increase the dendritic localization of BDNF and
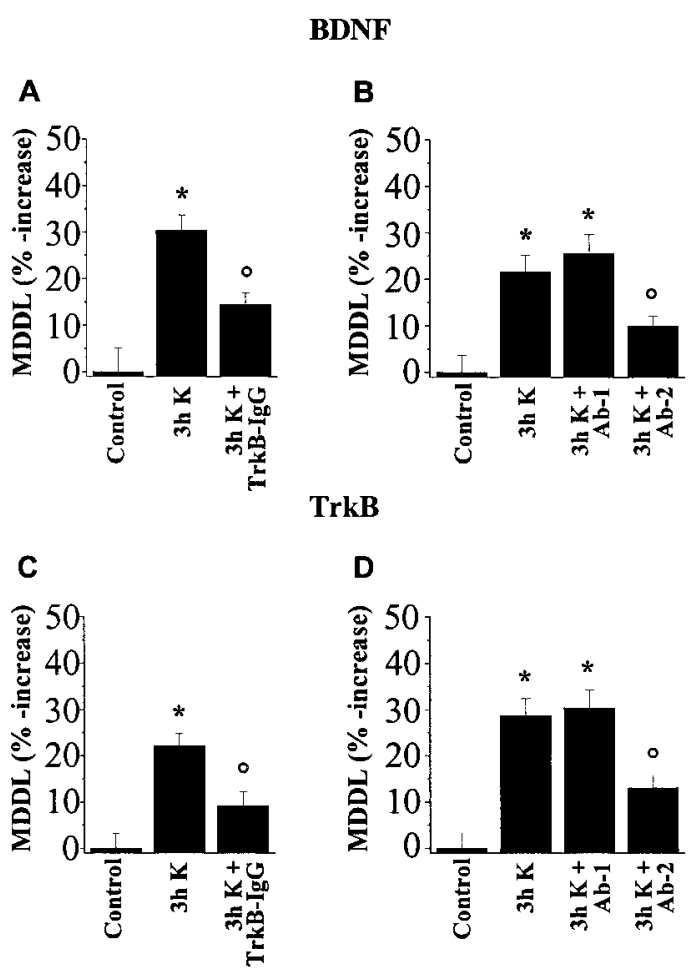

Figure 2. Effects of TrkB IgGs or polyclonal antibodies against BDNF on the KCl-induced increase in dendritic localization of BDNF-TrkB mRNAs. Quantification of the MDDL. Bars indicate the percentage-fold increase of the mean MDDL with respect to the controls. Error bars represent SE. $A$, BDNF mRNA. The average MDDL in control condition is $35.2 \mu \mathrm{m}$. The BDNF ligand TrkB IgG partially inhibits (53\% reduction; $3 h K+\operatorname{TrkB}-\operatorname{Ig} G)$ the MDDL increase for BDNF mRNA in $10 \mathrm{mM} \mathrm{KCl}$ (30\% increase; $3 h K)$. $B$, BDNF mRNA. The average MDDL in control condition is $33.6 \mu \mathrm{m}$. Not blocking polyclonal antibody against BDNF does not inhibit the MDDL increase for BDNF mRNA after $3 \mathrm{hr}$ depolarization in $10 \mathrm{mM} \mathrm{KCl}(25 \%$ increase; $3 h K+A b-1)$. A polyclonal antibody that blocks the action of BDNF partially inhibits $(52 \%$ reduction) the $10 \mathrm{mM} \mathrm{KCl}$ depolarization effects for BDNF mRNA (3h $K+$ $A b-2)$. $C$, TrkB mRNA. The average MDDL in control conditions is 36.3 $\mu \mathrm{m}$. Also for TrkB mRNA, TrkB IgG partially inhibits (60\% reduction; $3 h$ $K+\operatorname{TrkB} \operatorname{IgG})$ the MDDL increase in $10 \mathrm{mM} \mathrm{KCl}(22 \%$ increase; $3 h \mathrm{~K})$. $D$, TrkB mRNA. The average MDDL in control condition is $32.7 \mu \mathrm{m}$. Not blocking polyclonal antibody against BDNF does not inhibit the MDDL increase for TrkB mRNA after $3 \mathrm{hr}$ depolarization in $10 \mathrm{~mm} \mathrm{KCl}(30 \%$ increase; $3 h K+A b-1)$. A polyclonal antibody that blocks the action of BDNF partially inhibits $(55 \%$ reduction) the $10 \mathrm{mM} \mathrm{KCl}$ depolarization effects for TrkB mRNA $(3 h K+A b-2)$. *Significantly different with respect to the control $(p \leq 0.001)$. ${ }^{\circ}$ Significantly different with respect to the $3 \mathrm{hr} \mathrm{KCl}$ depolarization $(A, p \leq 0.001 ; B, p \leq 0.05 ; C, p \leq 0.002 ; D$, $p \leq 0.005)$.

TrkB mRNAs, but that the accumulation process itself required a longer time. Also, the extent of dendritic localization of BDNF and TrkB mRNAs appeared to be linked to the duration of depolarization.

\section{Role of endogenous BDNF in the $\mathrm{KCl}$-dependent dendritic targeting of BDNF and TrkB mRNAs}

Previous studies have shown that $\mathrm{KCl}$ depolarization of hippocampal neurons in culture induces an increase in BDNF release (Goodman et al., 1996) and that mRNAs packed in small granules translocate into the dendrites within $10 \mathrm{~min}$ from the beginning of the incubation with the neurotrophin NT-3 (Knowles and Kosik, 1997). To investigate whether endogenous BDNF contributes to the KCl-induced enhancement of MDDL 

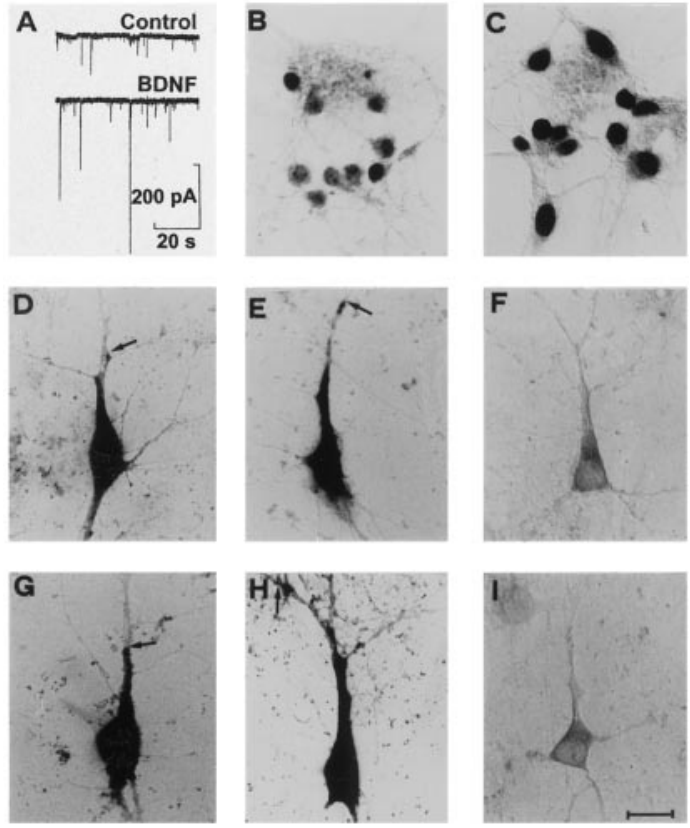

$\mathbf{J}$

BDNF

K
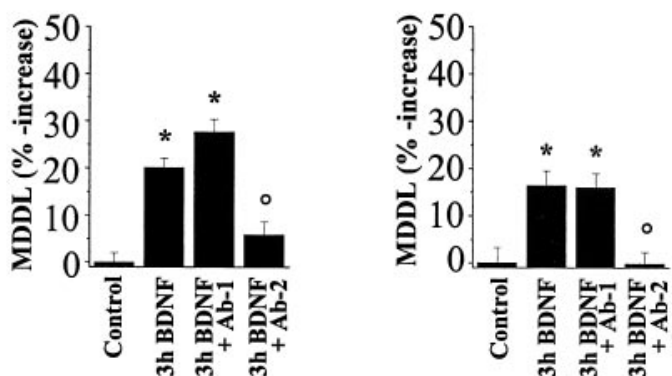

Figure 3. Dendritic targeting of BDNF-TrkB mRNAs is modulated by BDNF. $A$, Whole-cell patch-clamp recording of a hippocampal neuron. BDNF at $20 \mathrm{ng} / \mathrm{ml}$ increases the frequency and the amplitude of the bursts. $B$, Low level of zif immunostaining is present in the nuclei of untreated hippocampal neurons. $C$, High level of zif immunostaining is concentrated in the nuclei of cells incubated for $3 \mathrm{hr}$ with $20 \mathrm{ng} / \mathrm{ml}$ BDNF. $D-F$, Nonradioactive in situ hybridization on cultured hippocampal neurons with BDNF riboprobe. $D$, In control condition BDNF mRNA is localized in the proximal region of the dendrites (arrow). E, Cells treated for $3 \mathrm{hr}$ with $20 \mathrm{ng} / \mathrm{ml}$ BDNF show an increase in the BDNF mRNA dendritic localization with respect to the control (arrow), $F$, No staining is observed with BDNF sense riboprobe. $G-I$, Nonradioactive in situ hybridization with TrkB riboprobe. $G$, In control condition the mRNA staining for TrkB is localized in the proximal region of the dendrites (arrow). H, Neurons treated for $3 \mathrm{hr}$ with $20 \mathrm{ng} / \mathrm{ml}$ BDNF show an increase in the TrkB mRNA dendritic localization (arrow) with respect to the control. $I$, No staining is observed with TrkB sense riboprobe. Scale bar: $B-I, 20 \mu \mathrm{m}$ (shown in $I$ ). $J, K$, Quantification of the MDDL for BDNF and TrkB mRNAs in the presence of exogenous BDNF. Bars indicate the percentage-fold increase of the mean MDDL with respect to the controls. Error bars represent SE. J, BDNF mRNA. The average MDDL in control conditions is $31.8 \mu \mathrm{m}$. The MDDL for BDNF mRNAs was enhanced after incubation for $3 \mathrm{hr}$ with $20 \mathrm{ng} / \mathrm{ml}$ BDNF $(20 \%$ increase; $3 h \mathrm{BDNF}$ ); not blocking polyclonal antibody against BDNF does not inhibit the MDDL increase for BDNF mRNA after $3 \mathrm{hr}$ incubation with $20 \mathrm{ng} / \mathrm{ml}$ BDNF ( $3 h B D N F+A b-1)$; a polyclonal antibody that blocks the action of BDNF inhibits (71\% reduction) the BDNFinduced increase of MDDL for BDNF mRNA $(3 h B D N F+A b-2) . K$, TrkB mRNA. The average MDDL in control conditions is $32.7 \mu \mathrm{m}$. Also for TrkB mRNA the MDDL was enhanced after BDNF incubation (16\% increase; $3 h \mathrm{BDNF}$ ); not blocking polyclonal antibody against BDNF does not inhibit the MDDL increase for TrkB mRNA after $3 \mathrm{hr}$ incuba- for the mRNAs under study, neurons were incubated in $10 \mathrm{~mm}$ $\mathrm{KCl}$ for $3 \mathrm{hr}$ in the presence of $3 \mu \mathrm{g} / \mathrm{ml}$ TrkB immunoadhesin (TrkB IgG) as a ligand scavenger. This led to a significant inhibition in BDNF mRNA localization (53\% reduction) with respect to the MDDL induced by $\mathrm{KCl}$ depolarization in the absence of TrkB IgGs (Fig. $2 A$; the average MDDL in control condition was $35.2 \mu \mathrm{m})$. Likewise, also for TrkB mRNA the dendritic labeling observed after $3 \mathrm{hr}$ incubation in $10 \mathrm{~mm} \mathrm{KCl}$ was significantly reduced when the TrkB IgGs were present during the depolarization time (60\% reduction) (Fig. $2 C$; the average MDDL in control condition was $36.3 \mu \mathrm{m})$.

The TrkB IgGs cannot mainly discriminate between BDNF and NT-4. To further investigate which of the two neurotrophins was involved in the increase in MDDL during $\mathrm{KCl}$ depolarization, two types of rabbit polyclonal antibody against BDNF were added during depolarization of the cultures (Fig. 2B,D). The first antibody does not block the action of BDNF (Ab-1) (see Materials and Methods), whereas the second one does so (Ab-2) (Yan et al., 1997). Ab-2 antibodies inhibited (52\% reduction) the $\mathrm{KCl}-$ induced MDDL increase for BDNF mRNA, whereas Ab-1 antibodies did not (Fig. $2 B$; the average MDDL in control condition was $33.6 \mu \mathrm{m}$ ). A similar inhibition of MDDL (55\% reduction) was found for TrkB mRNA, in the presence of neutralizing antiBDNF Ab-2 antibodies (Fig. 2D, the average MDDL in control condition was $32.7 \mu \mathrm{m})$.

Taken together, these results suggest that endogenously released BDNF, acting extracellularly, contributes to the enhancement of the dendritic targeting of both BDNF and TrkB mRNA induced by $10 \mathrm{~mm} \mathrm{KCl}$ depolarization.

\section{Exogenous BDNF increases the dendritic localization of BDNF and TrkB mRNAs in the absence of $\mathrm{KCl}$ depolarization}

To investigate the contribution of BDNF to the increased dendritic localization of BDNF-TrkB mRNAs, exogenous BDNF was added to the culture ( $20 \mathrm{ng} / \mathrm{ml}$ for $3 \mathrm{hr}$ ), in the absence of $\mathrm{KCl}$ depolarization. The activity of BDNF on hippocampal neurons was verified by electrophysiological recordings and by monitoring the BDNF-dependent induction of immediate early gene products. Previous studies have shown that BDNF influences the synaptic activity of cultured neurons (Lohof et al., 1993; Lessmann et al., 1994; Carmignoto et al., 1997; Li et al., 1998). As exemplified in Figure $3 A$, BDNF induced an increase in the frequency and in the amplitude of EPSPs with respect to control.

BDNF treatment ( $3 \mathrm{hr}$ ) of hippocampal neurons induced also a marked increase in nuclear accumulation of the early gene products zif (Fig. 3, compare B, C) and c-fos (data not shown).

Having established that in these neurons BDNF can activate distinct transduction pathways, leading to membrane and to intracellular responses, we investigated the ability of BDNF to influence the dendritic accumulation of BDNF-TrkB mRNAs.

After a $3 \mathrm{hr}$ incubation with BDNF, the in situ staining for both BDNF and TrkB mRNAs was found at a much greater distance from the cell body than in control cells. Representative cells are shown in Figure 3D-I (BDNF mRNA, Fig. 3D,E, control cells

\section{$\leftarrow$}

tion with $20 \mathrm{ng} / \mathrm{ml} \mathrm{BDNF}(3 h B D N F+A b-1)$; a polyclonal antibody that blocks the action of BDNF completely inhibits (100\% reduction) the BDNF-induced increase of MDDL for TrkB mRNA ( $3 h B D N F+A b-2)$. *Significantly different with respect to the control $(J, p \leq 0.001 ; K, 3 h$ $B D N F, p \leq 0.01 ; K, 3 h B D N F+A b-1, p \leq 0.02)$. ${ }^{\circ}$ Significantly different with respect to the $3 \mathrm{hr} \operatorname{BDNF}$ incubation $(J, p \leq 0.005 ; K, p \leq 0.001)$. 

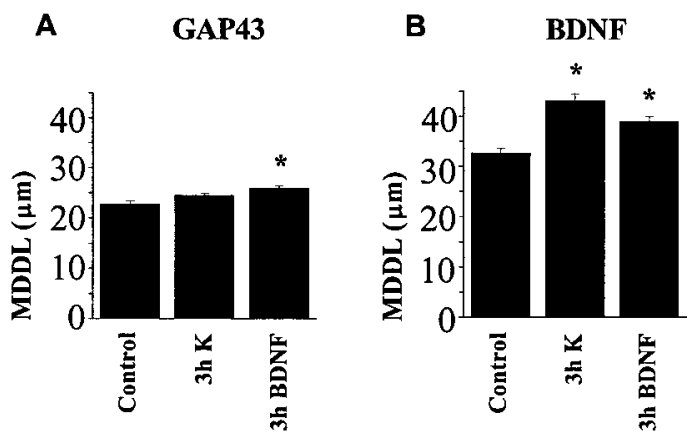

Figure 4. High potassium and BDNF incubation increases the dendritic localization of BDNF, but not of GAP-43 mRNAs in cultured hippocampal neurons. Hippocampal neurons were incubated for $3 \mathrm{hr}$ with $10 \mathrm{~mm}$ $\mathrm{KCl}$ or $20 \mathrm{ng} / \mathrm{ml} \mathrm{BDNF}$ and processed for in situ hybridization with BDNF or GAP-43 riboprobes. Bars in $A$ and $B$ indicate the mean MDDL measured in micrometers. Error bars represent SE. $A$, GAP-43 mRNA. The average MDDL in control conditions is $22.7 \mu \mathrm{m}$. There is a small increase in the MDDL for GAP-43, after incubation with $\mathrm{KCl}$ or BDNF. The mean MDDL for GAP-43 after $\mathrm{KCl}(3 h K)$ or BDNF ( $3 h$ BDNF) stimulation is always $<26 \mu \mathrm{m}$ (24.4 and $25.9 \mu \mathrm{m}$ for $3 h K$ and $3 h B D N F$, respectively). $B$, BDNF mRNA. The average MDDL in control conditions is $32.6 \mu \mathrm{m}$. The MDDL for BDNF mRNAs is enhanced after $\mathrm{KCl}$ $(3 h K ; 43.2 \mu \mathrm{m})$ and BDNF incubation (3h BDNF; $39.0 \mu \mathrm{m})$. *Significantly different with respect to the control $(A, p \leq 0.01 ; B, p \leq 0.001)$.

and BDNF-treated cells, respectively; TrkB mRNA, Fig. 3G, $H$, control cells and BDNF-treated cells, respectively). The intensity of the in situ staining for both BDNF and TrkB mRNAs was not increased after incubation with BDNF. In situ hybridization with BDNF and TrkB sense riboprobes is shown in Figure 3, $F$ and $I$, respectively. The results of the quantitative analysis are shown in Figure $3 J$ for BDNF and Figure $3 K$ for TrkB mRNA (for this set of experiments the average MDDL in control condition was 31.8 $\mu \mathrm{m}$ for BDNF mRNA and $32.7 \mu \mathrm{m}$ for TrkB mRNA), demonstrating that addition of exogenous BDNF to hippocampal cultures led to an extension of the dendritic localization of BDNF $(20 \%$ increase; MDDL, $38.3 \mu \mathrm{m})$ and TrkB (16\% increase; MDDL, $38.1 \mu \mathrm{m}$ ) mRNAs, in the absence of $\mathrm{KCl}$ depolarization. This increase in MDDL was abolished by co-incubation with a blocking anti-BDNF antibody (Ab-2), but not with the nonneutralizing one (Ab-1).

To determine whether the effect of BDNF on the dendritic localization of BDNF and TrkB mRNAs reflects a generalized increase in mRNA translocation, we examined the subcellular distribution of other mRNAs. Figure 4 shows the results for the GAP43 mRNA. In control hippocampal neurons, this mRNA was found to be localized to the cell soma and to the very proximal region of dendrites, with a mean MDDL of $22.7 \mu \mathrm{m}$. Incubation for $3 \mathrm{hr}$ in $10 \mathrm{~mm} \mathrm{KCl}$ or $20 \mathrm{ng} / \mathrm{ml} \mathrm{BDNF}$ did not change the overall subcellular distribution of growth-associated protein (GAP)-43 mRNA (MDDL, 24.4 and $25.9 \mu \mathrm{m}$, respectively) (Fig. $4 A$ ), despite a clearly visible increase in the intensity of the staining (data not shown). Only a very minor increase in the MDDL was observed after BDNF incubation, with GAP-43 mRNA remaining confined to the very proximal dendritic compartment. The extent of MDDL observed for GAP-43 mRNA after BDNF incubation is, however, well below the MDDL value observed for BDNF mRNA in sister cultures, either in the absence of any stimulation (MDDL, $32.6 \mu \mathrm{m}$ ) or after incubation for $3 \mathrm{hr}$ with $10 \mathrm{~mm} \mathrm{KCl} \mathrm{(3} \mathrm{hr} \mathrm{K)} \mathrm{or} 20 \mathrm{ng} / \mathrm{ml} \mathrm{BDNF}$ ( $3 \mathrm{hr}$ BDNF) (3 hr K: $32 \%$ increase, $43.2 \mu \mathrm{m} ; 3 \mathrm{hr}$ BDNF: $20 \%$ increase, 39.0 $\mu \mathrm{m})$ (Fig. $4 B$ ). These results demonstrated that $\mathrm{KCl}$ and BDNF
A
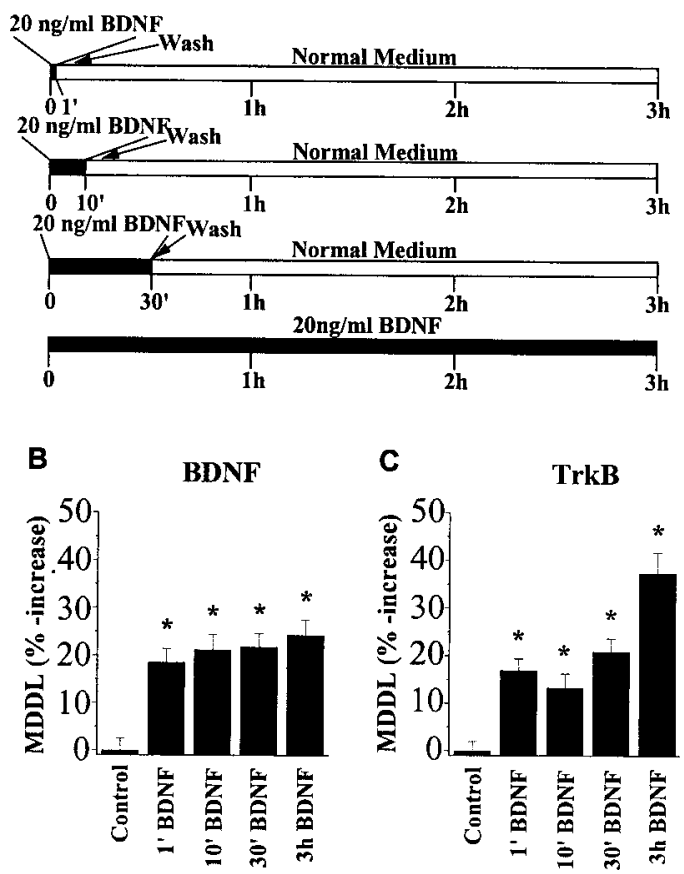

Figure 5. Time course of BDNF-induced dendritic mRNA targeting. Quantification of the MDDL for BDNF-TrkB mRNAs in the presence of exogenous BDNF. $A$, Hippocampal neurons were incubated for 1, 10, 30 , and $180 \mathrm{~min}$ with $20 \mathrm{ng} / \mathrm{ml} \mathrm{BDNF}$, washed, and incubated in normal medium up to a total of $3 \mathrm{hr}$ from the beginning of the experiment. Bars in $B$ and $C$ indicate the percentage-fold increase of the mean MDDL with respect to the controls. Error bars represent SE. $B$, BDNF mRNA. The average MDDL in control conditions is $30.2 \mu \mathrm{m}$. The MDDL for BDNF mRNAs was progressively enhanced with increasing time of BDNF incubation: $1,10,30$, and $180 \mathrm{~min}\left(1^{\prime}, 10^{\prime}, 30^{\prime}\right.$, and $3 h \mathrm{BDNF} ; 18,21,22$, and $24 \%$ increase, respectively). $C$, TrkB mRNA. The average MDDL in control conditions is $31.5 \mu \mathrm{m}$. Also for TrkB mRNA the MDDL was enhanced after BDNF incubation: $1,10,30$, and $180 \mathrm{~min}\left(1^{\prime}, 10^{\prime}, 30^{\prime}\right.$, and $3 h \mathrm{BDNF} ; 16,13,21$, and $37 \%$ increase, respectively). 'Significantly different with respect to the control $(B, C, p \leq 0.001,1 \mathrm{~min}, 30 \mathrm{~min}$, and $3 \mathrm{hr} \mathrm{BDNF}$; $C, p \leq 0.01,10 \mathrm{~min} \mathrm{BDNF})$.

incubations did not induce an accumulation of GAP-43 mRNA in the dendrites, in contrast to BDNF mRNA.

The time course of BDNF-induced dendritic mRNA targeting was investigated by incubating the cultures with BDNF for varying times (from $1 \mathrm{~min}$ to $3 \mathrm{hr}$ ) and processing the cultures after 3 hr from the beginning of the incubation (Fig. $5 A$ ). For this set of experiments the average MDDL in control condition was $30.2 \mu \mathrm{m}$ for BDNF mRNA and $31.5 \mu \mathrm{m}$ for TrkB mRNA. As shown in Figure 5, $B$ and $C$ (for BDNF and TrkB mRNA, respectively), a significant increase in dendritic targeting was already apparent after 1 min with BDNF, with greater stimulations being observed after longer incubation times with BDNF. In the case of TrkB mRNA, we observed a marked stepwise increase in MDDL after $3 \mathrm{hr}$ incubation with BDNF (Fig. 5C). The time course experiment showed that a brief incubation with BDNF was sufficient to increase the dendritic localization of BDNF-TrkB mRNAs, observed after $3 \mathrm{hr}$.

\section{Dissecting the intracellular mechanism for BDNF- induced dendritic targeting of BDNF-TrkB mRNAs}

The tyrosine kinase receptor TrkB is a mediator of many physiological effects of BDNF (Lewin and Barde, 1996). In hippocampal neurons, both BDNF and TrkB receptor are often coex- 

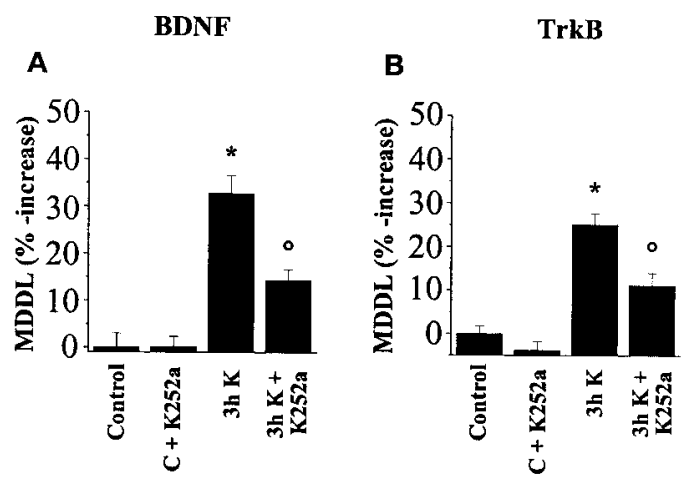

C
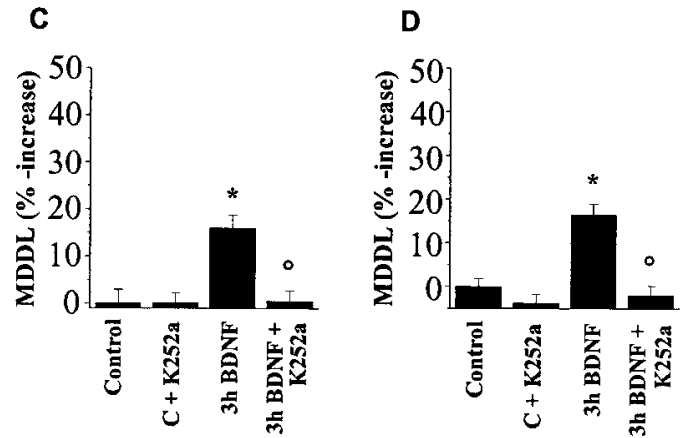

Figure 6. Effects of the protein tyrosine kinase inhibitor on the $\mathrm{KCl}$ and BDNF-induced increase in dendritic localization of BDNF-TrkB mRNAs. Hippocampal neurons were preincubated for $45 \mathrm{~min}$ with $30 \mathrm{nM}$ K252a before starting the $3 \mathrm{hr}$ depolarization in $10 \mathrm{~mm} \mathrm{KCl}$ or the $3 \mathrm{hr}$ incubation in $20 \mathrm{ng} / \mathrm{ml} \mathrm{BDNF}$ in the continuous presence of K252a. Bars indicate the percentage-fold increase of the mean MDDL with respect to the controls. Error bars represent SE. The average MDDL in control conditions is 31.7 and $30.0 \mu \mathrm{m}$ for BDNF and TrkB mRNA, respectively. $A$, K252a partially inhibits (57\% reduction; $3 h K+K 252 a$ ) the MDDL increase for BDNF mRNA in $10 \mathrm{~mm} \mathrm{KCl} \mathrm{(32 \%} \mathrm{increase;} 3 h K)$. B. Also for TrkB mRNA K252a partially inhibits (45\% reduction; $3 h K+K 252 a$ ) the MDDL increase in $10 \mathrm{mM} \mathrm{KCl}(25 \%$ increase; $3 h \mathrm{~K})$. C, K252a inhibits $(88 \%$ reduction; $3 h B D N F+K 252 a)$ the BDNF-induced increase of MDDL for BDNF mRNA (16\% increase; $3 h$ BDNF). D, K252a completely abolished (100\% reduction; $3 h B D N F+K 252 a)$ the BDNFinduced increase of MDDL for TrkB mRNA (17\% increase; $3 h B D N F$ ). *Significantly different with respect to the control ( $p \leq 0.001)$. ${ }^{\circ}$ Significantly different with respect to the $3 \mathrm{hr} \mathrm{KCl}$ depolarization or $3 \mathrm{hr}$ incubation with $\operatorname{BDNF}(p \leq 0.001)$.

pressed (Kokaia et al., 1993; Miranda et al., 1993). We therefore investigated the possible involvement of the TrkB receptor in the enhancement of MDDL for BDNF-TrkB mRNAs, observed after $\mathrm{KCl}$ depolarization or BDNF treatment. For this set of experiments, the average MDDL in control condition was 31.7 $\mu \mathrm{m}$ for BDNF mRNA and $30.0 \mu \mathrm{m}$ for TrkB mRNA. Hippocampal neurons were incubated with $10 \mathrm{~mm} \mathrm{KCl}$ or with $20 \mathrm{ng} / \mathrm{ml}$ $\mathrm{BDNF}$ for $3 \mathrm{hr}$, in the presence of $\mathrm{K} 252 \mathrm{a}(30 \mathrm{nM})$, a broad protein kinase inhibitor that prefers Trk receptors (Berg et al., 1992). This led to a significant reduction in the MDDL for BDNF-TrkB mRNAs, with respect to that measured in the absence of K252a: $57 \%$ reduction for BDNF mRNA (Fig. $6 A$ ) and $45 \%$ for TrkB mRNA (Fig. 6B).

This confirms that activation of a tyrosine kinase receptor can contribute to the $\mathrm{KCl}$-induced dendritic accumulation of BDNFTrkB mRNAs, possibly by locally released BDNF. K252a also inhibited the dendritic accumulation of BDNF-TrkB mRNAs induced by exogenous BDNF: in this case, the inhibition was complete (Fig. 6C,D), suggesting that this action of BDNF in- volved the activation of tyrosine kinases, most likely linked to the TrkB receptors.

To further investigate the intracellular pathways involved in the modulation of BDNF-TrkB mRNAs dendritic targeting by BDNF, we used drugs interfering at different levels with signal transduction pathways activated by the interaction of BDNF with TrkB receptors: (1) the $\mathrm{MAP} / \mathrm{ERK}$ kinase (MEK) inhibitor PD-098059 (Dudley et al., 1995), (2) the $\mathrm{Ca}^{2+} /$ calmodulindependent protein kinase CAMK II and IV inhibitor KN-62 (Tokumitsu et al., 1990), and (3) the a PI-3 kinase inhibitor wortmannin (for review, see Ui et al., 1995). The average MDDL in control condition was $34.4 \mu \mathrm{m}$ (Fig. 7A), $33.7 \mu \mathrm{m}$ (Fig. 7B), 33.4 $\mu \mathrm{m}$ (Fig. 7C), 35.2 (Fig. 7D), $33.4 \mu \mathrm{m}$ (Fig. 7E), and $35.2 \mu \mathrm{m}$ (Fig. 7E). Hippocampal neurons were preincubated for $45 \mathrm{~min}$ with each one of these drugs and then treated for $3 \mathrm{hr}$ with BDNF, in the continuous presence the drugs. Although PD-098059 and KN-62 did not significantly affect the BDNFinduced dendritic accumulation of both BDNF and TrkB mRNAs (Fig. $7 C-F$ ), the PI-3 kinase inhibitor wortmannin strongly reduced the dendritic accumulation of both mRNAs $(75 \%$ reduction; Fig. 7A,B). The activity of PD-098059 was assessed in a parallel bioassay on PC12 cells, showing a complete inhibition of NGF-induced neurite outgrowth, as also obtained with K252a (data not shown).

Thus, the increased accumulation of BDNF-TrkB mRNAs in the dendrites by BDNF involves activation of PI-3 kinase, but not of the MAP kinase or of the CaM kinase cascades.

BDNF stimulates synaptic activity and neurotransmitter release (Fig. 3A; Li et al., 1998) in hippocampal cultures. To address the possible involvement of BDNF-induced release of neurotransmitters at the synapses in the enhancement of dendritic accumulation of mRNAs by this neurotrophin, we simultaneously blocked non-NMDA receptor-mediated EPSPs by CNQX (20 mM), NMDA receptor-mediated EPSPs by APV (50 mM), GABA-A receptor-mediated IPSPs by picrotoxin (100 mM), GABA-B receptor-mediated IPSPs by CGP 35348 (10 mM), and $\mathrm{Na}^{+}$channels by TTX $(0.5 \mathrm{~mm})$. Hippocampal cultures were preincubated with this antagonist cocktail for $45 \mathrm{~min}$, followed by addition of BDNF for $3 \mathrm{hr}$ in the continuous presence of the antagonists (Fig. 8A). To verify if the antagonist cocktail interfered nonspecifically with the activity of BDNF, the ability of BDNF to induce zif immunoreactivity was monitored in hippocampal neurons. In the presence of the antagonist cocktail, zif immunoreactivity was still induced by BDNF (compare Fig. $8 B, C$ with Fig. $3 B, C$ ). The effect of BDNF on the dendritic accumulation of BDNF-TrkB mRNAs was determined. For this set of experiments the average MDDL in control condition was $33.6 \mu \mathrm{m}$ for BDNF mRNA and $35.1 \mu \mathrm{m}$ for Trkb mRNA. The results in Figure $8, D$ and $E$, show that the dendritic mRNA accumulation induced by BDNF was not affected by the antagonist cocktail. These results suggest that the action of exogenous BDNF was not mediated by BDNF-induced synaptically released neurotransmitters and that, most likely, was a direct action on the cells where the mRNA accumulation is observed.

\section{DISCUSSION}

An increasing body of evidence suggests a role for the BDNFTrkB system in the short- and long-term modulation of synaptic efficacy (Schuman, 1999). It is therefore noteworthy that the mRNAs for both the BDNF ligand and the TrkB receptor are accumulated in the dendrites in an activity-dependent way, where they contribute to the local synthesis of the corresponding pro- 

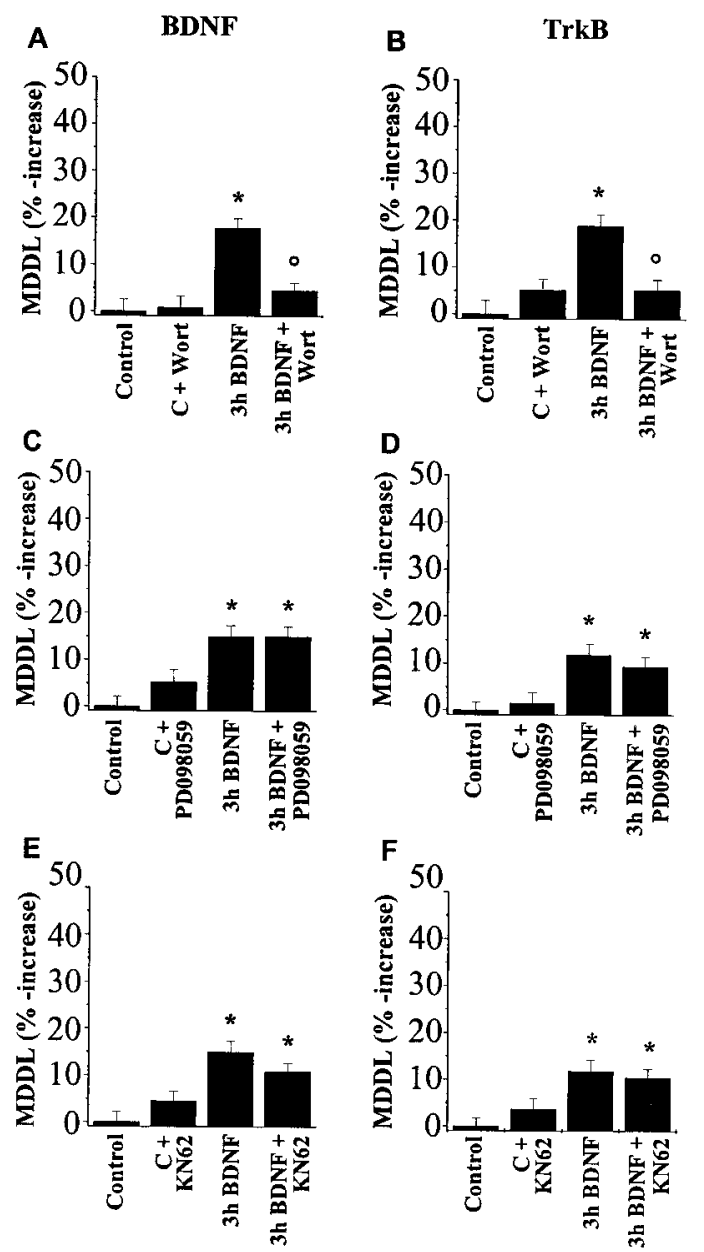

Figure 7. Effects of intracellular pathways inhibitors in the modulation of dendritic targeting of BDNF-TrkB mRNAs induced by BDNF. A panel of drugs was used: (1) the PI-3 kinase inhibitor wortmannin (100 nM), (2) the MAP kinase kinase inhibitor PD-098059 $(50 \mu \mathrm{M})$, and (3) the CaMK II and IV inhibitor KN-62 $(10 \mu \mathrm{M})$. Hippocampal neurons were preincubated for $45 \mathrm{~min}$ with each of these drugs and then treated for $3 \mathrm{hr}$ with $\mathrm{BDNF}$, in the continuous presence of each drug. Bars indicate the percentage-fold increase of the mean MDDL with respect to the controls. Error bars represent SE. $A$, BDNF mRNA. The average MDDL in control conditions is $34.4 \mu \mathrm{m}$. Wortmannin inhibits (76\% reduction; $3 h$ $B D N F+$ Wort $)$ the BDNF-induced increase of MDDL for BDNF mRNA $(18 \%$ increase; $3 h B D N F)$. B, TrkB mRNA. The average MDDL in control conditions is $33.7 \mu \mathrm{m}$. Also for TrkB mRNA wortmannin inhibits (73\% reduction; $3 h B D N F+W o r t)$ the BDNF-induced increase of MDDL (19\% increase; $3 h \quad B D N F)$. $C$, BDNF mRNA. The average MDDL measured is $33.4 \mu \mathrm{m}$. PD-098059 does not inhibit $(3 h B D N F+$ $P D-098059)$ the BDNF-induced increase of MDDL (15\% increase; $3 h$ $B D N F)$. $D$, TrkB mRNA. The average MDDL in control conditions is $35.2 \mu \mathrm{m}$. Also for TrkB mRNA PD-098059 does not inhibit (3h BDNF + $P D-098059)$ the BDNF-induced increase of MDDL (12\% increase; $3 h$ $B D N F)$. E, BDNF mRNA. The average MDDL in control conditions is $33.4 \mu \mathrm{m}$. KN-62 does not inhibit ( $3 h B D N F+K N-62)$ the BDNF-induced increase of MDDL (15\% increase; $3 h B D N F) . F$, TrkB mRNA. The average MDDL in control conditions is $35.2 \mu \mathrm{m}$. Also for TrkB mRNA KN-62 does not inhibit ( $3 h B D N F+K N$-62) the BDNF-induced increase of MDDL (12\% increase; $3 h B D N F)$. *Significantly different with respect to the control ( $p \leq 0.001)$. ${ }^{\circ}$ Significantly different with respect to the $3 \mathrm{hr}$ BDNF incubation $(A, B, p \leq 0.001)$.

teins (Tongiorgi et al., 1997). The large majority of hippocampal neurons coexpress both BDNF and TrkB (Miranda et al., 1993), suggesting the existence of autocrine loops at the cellular level, as demonstrated in sensory neurons (Acheson et al., 1995). Because
A
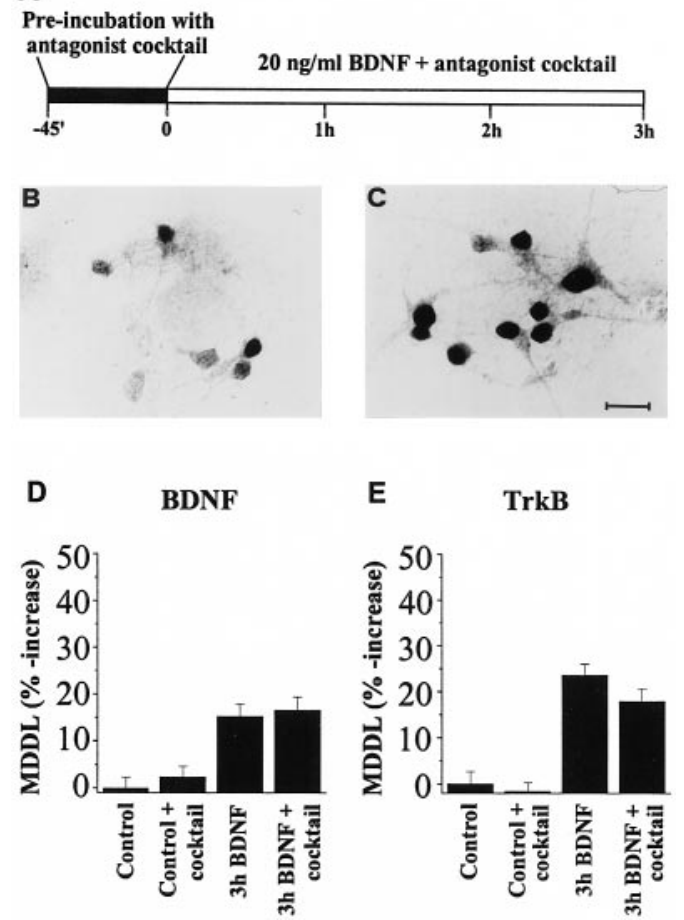

Figure 8. The dendritic accumulation of BDNF-TrkB mRNA induced by $\mathrm{BDNF}$ is not affected by the antagonist cocktail. $A$, Hippocampal cultures were preincubated with the antagonist cocktail (in $\mu \mathrm{M}$ : 20 CNQX, 50 APV, 100 picrotoxin, 10 CGP 35348, and 0.5 TTX) for $45 \mathrm{~min}$, followed by addition of BDNF for $3 \mathrm{hr}$ in the continuous presence of the antagonists. $B$, Low level of zif immunostaining is present in the nuclei of control hippocampal neurons incubated with the antagonist cocktail for 3 $\mathrm{hr}$ and $45 \mathrm{~min}$. $C$, High level of zif immunostaining is concentrated in the nuclei of cells incubated for $3 \mathrm{hr}$ with $20 \mathrm{ng} / \mathrm{ml} \mathrm{BDNF}$ in the continuous presence of antagonist cocktail. Scale bar: $B, C, 20 \mu \mathrm{m}$ (shown in $C$ ). Bars in $D$ and $E$ indicate the percentage-fold increase of the mean MDDL with respect to the controls. Error bars represent SE. $D$, BDNF mRNA. The average MDDL in control conditions is $33.6 \mu \mathrm{m}$. Antagonist cocktail does not inhibit $(3 h B D N F+$ cocktail $)$ the BDNF-induced increase of MDDL (16\% increase; $3 h$ BDNF). E, TrkB mRNA. The average MDDL in control conditions is $35.1 \mu \mathrm{m}$. Also for TrkB mRNA antagonist cocktail does not inhibit (3h BDNF + cocktail) the BDNF-induced increase of MDDL (24\% increase; $3 h B D N F)$. *Significantly different with respect to the control $(p \leq 0.001)$.

$\mathrm{KCl}$ depolarization induces the secretion of neurotrophins (Blöchl and Thoenen, 1995, 1996; Goodman et al., 1996), we postulated that BDNF and TrkB are part of a local autocrine (or paracrine) loop (Tongiorgi et al., 1997). One aspect of this hypothesis is that the released BDNF might contribute to the dendritic accumulation of its own mRNA, and of that for TrkB. The experiments described in this paper were aimed at testing this hypothesis.

The increased accumulation of BDNF and TrkB mRNAs in dendrites induced by BDNF is, in principle, attributable to the stimulation of a specific transport mechanism and/or to an increased half-life of the two mRNAs, constitutively transported in the dendritic compartment. Evidence for both mechanisms, in different systems, has been presented (Ainger et al., 1993; Morris, 1997; Carson et al., 1998).

It is becoming increasingly evident that there are distinct degrees of dendritic localization for different mRNAs (Steward, 1997). As shown previously (Tongiorgi et al., 1997, their Fig. 4), after $\mathrm{KCl}$ stimulation several dendrites of hippocampal neurons 
are filled with BDNF and TrkB mRNA for their entire length, in many cases up to $>150 \mu \mathrm{m}$, with most dendrites being "filled" for more than half of their length. For some other mRNAs, such as Arg3.1/Arc (Link et al., 1995; Lyford et al., 1995) and CAM II kinase (Burgin et al., 1990), the proportion of cells with a complete distal dendritic filling is higher (Steward, 1997; Kuhl and Skehel, 1998). The functional significance of these differences is presently unclear, and the mechanisms that underlie this differential localization remain to be established.

The results obtained in cultured neurons in vitro may find a correlate in vivo. Studies of BDNF mRNA in vivo indicate that under most circumstances, the mRNA appears to be localized exclusively in the region of the cell body (Lauterborn et al., 1996; Schmidt-Kastner et al., 1996). However, we have recently shown that the dendritic localization of BDNF mRNA can be detected in dendrites in vivo under certain circumstances (Tongiorgi et al., 1999), showing a prominent dendritic staining up to $150 \mu \mathrm{m}$ from the cell bodies. The distribution of BDNF mRNA in vivo after seizures has been previously studied with radioactive in situ hybridization (Dugich-Djordjevic et al., 1992), detecting a proximal dendritic localization. We believe that the use of an optimized procedure of nonradioactive in situ hybridization has allowed a much greater sensitivity, spatial resolution, and tissue preservation (Tongiorgi et al., 1998). It remains to be seen whether BDNF can modulate the dendritic localization of its own mRNA in vivo as well as in vitro.

The KCl-induced mRNA accumulation in dendrites is partially reduced by blocking the activation of NMDA-AMPA glutamate receptors of voltage-dependent L-type calcium channels (Tongiorgi et al., 1997) and of TrkB receptors (this paper). Blocking the activation of TrkB during a depolarizing stimulus leads only to a $50 \%$ reduction in the MDDL for BDNF-TrkB mRNAs. Conversely, the dendritic accumulation induced by BDNF was smaller than that induced by $\mathrm{KCl}$ stimulation. Altogether, this suggests that the actions of $\mathrm{KCl}$ and of BDNF on mRNA targeting are at least in part independent. The effect of BDNF (and of $\mathrm{KCl}$ ) on the subcellular distribution of BDNF and TrkB mRNAs appears not to reflect a generalized increase in RNA translocation, as shown by studying the control mRNA GAP-43 (Chicurel et al., 1993; Landry et al., 1994). Indeed, we found that in hippocampal cultures the GAP-43 mRNA is found only in the soma and in the proximal region of dendrites, even after treatment with $\mathrm{KCl}$ or BDNF.

BDNF pulses as brief as 1 min induced a significant increase in the MDDL for BDNF-TrkB mRNAs, provided that time was allowed for the accumulation to build up. We cannot exclude that the rapid induction by $\mathrm{BDNF}(1 \mathrm{~min})$ might involve a more prolonged action of BDNF itself after the pulse. This might be possibly attributable to continuing activity after internalization, to persistent binding to the TrkB receptor for a time longer than the pulse (Dechant et al., 1994), or to the release of more BDNF after the wash-out (Canossa et al., 1997).

BDNF has been shown to enhance neurotransmitter release in hippocampal neurons (Li et al., 1998). We found that the stimulation of dendritic TrkB-BDNF mRNA targeting by BDNF occurs also in the presence of pharmacological antagonists of neurotransmitter receptors. This supports the view that BDNF acts in a direct way, on the same cell to which BDNF binds, independent of released neurotransmitters. Although the mRNA accumulation induced by $\mathrm{KCl}$ is blocked by TTX, BDNF can induce mRNA accumulation also in the presence of this drug (Fig. 8D,E). Interestingly, the "baseline" MDDL observed in control cultures is not reduced by TTX and synaptic receptor inhibitors. The involvement of the recently identified TrkBactivated TTX-insensitive sodium channel (Kafitz et al., 1999) in causing the dendritic localization of BDNF-TrkB mRNAs is a possibility that deserves future investigations.

Enhancement of the dendritic targeting of BDNF-TrkB mRNAs by BDNF involved a PI-3 kinase-dependent pathway. Future experiments with other pharmacological inhibitors (e.g., LY294002) or with isoform-specific antibodies (Vanhaesebroeck et al., 1999) will allow to firmly establish the involvement of PI-3 kinase isoforms in this process. Known effectors activated by PI-3 kinase include the Akt kinase, cytoskeletal proteins (for review, see Bos, 1995; Downward, 1995, 1998; Coffer et al., 1998; Corvera and Czech, 1998) and proteins regulating mRNA translation, such as p70 S6 kinase and the eIF4E-binding proteins 4E-BP1 and 4E-BP2 (Burnett et al., 1998; Polakiewicz et al., 1998). There is a striking correlation between the rapid time course of PI-3 kinase activation in neurons by growth factors (D'Mello et al., 1997) and the rapid induction of mRNA accumulation by BDNF. Moreover, this signaling pathway is a common target for both growth factor and integrin receptor signaling (Plopper et al., 1995), an intriguing coincidence because integrin binding and mechanical tension have been shown to induce movement of mRNA and ribosomes to focal adhesion complexes (Chicurel et al., 1998).

The efficacy of each synaptic connection of a given neuron can be independently modulated. Whereas short-term changes in synaptic efficacy probably involve post-translational modifications, long-term changes require the expression of new genes and hence, most often, but not always (Gottschalk et al., 1999), the synthesis of new proteins. For instance, the production of new, although unidentified, proteins is necessary for the long-lasting phases of hippocampal LTP (Kang and Schuman, 1996). At least two distinct mechanisms can, in principle, lead to the activitydependent accumulation of new proteins at the synapse. In one, retrograde synapse-to-nucleus signals are required to travel to the cell body and induce the transcription of new genes (Deisseroth et al., 1996; Crino et al., 1998). The newly encoded proteins would be synthesized in the cell body and captured by the activated synapse by a transient tag established during the initial stimulation (Schuman, 1997; Frey and Morris, 1998). However, the nature of such tag remains unknown, as do the proteins that may be recruited. A second mechanism that might be responsible, in principle, for the recruitment of new proteins at activated synpases involves the delivery of selected RNAs to postsynaptic dendritic sites. A growing number of $\mathrm{mRNAs}$ has been found in dendrites (Garner et al., 1988; Burgin et al., 1990; Furuichi et al., 1993; Link et al., 1995; Lyford et al., 1995; Gazzaley et al., 1997; Herb et al., 1997; Prakash et al., 1997; Racca et al., 1997) and, for some of these, the dendritic localization was found to be stimulated by electrical activity (Tongiorgi et al., 1997; Roberts et al., 1998; Steward et al., 1998). Selected dendritic mRNAs, docked at a synaptic target site, would then be translated locally and selectively upon demand, for example as a result of synaptic activity (Ouyang et al., 1999; Steward and Halpain, 1999), or of neurotrophin stimulation (Crino and Eberwine, 1996; Kang and Schuman, 1996).

The results described in this paper provide further evidence consistent with this scheme, showing a direct action of the neurotrophin BDNF on the dendritic accumulation of its own mRNA, as well as of the mRNA encoding for its receptor. 


\section{REFERENCES}

Acheson A, Conover JC, Fandl JP, DeChiara TM, Russell M, Thadani A, Squinto SP, Yancopoulos GD, Lindsay RM (1995) A BDNF autocrine loop in adult sensory neurons prevents cell death. Nature 374:450-453.

Aigner L, Arber S, Kapfhammer JP, Laux T, Schneider C, Botteri F, Brenner HR, Caroni P (1995) Overexpression of the neural growthassociated protein GAP-43 induces nerve sprouting in the adult nervous system of transgenic mice. Cell 83:269-278.

Ainger K, Avossa D, Morgan F, Hill SJ, Barry C, Barbarese E, Carson JH (1993) Transport and localization of exogenous myelin basic protein mRNA microinjected into oligodendrocytes. J Cell Biol 123:431-441.

Berg MM, Sternberg DW, Parada LF, Chao MV (1992) K-252a inhibits nerve growth factor-induced trk proto-oncogene tyrosine phosphorylation and kinase activity. J Biol Chem 267:13-16.

Blöchl A, Thoenen H (1995) Characterization of nerve growth factor (NGF) release from hippocampal neurons: evidence for a constitutive and an unconventional sodium-dependent regulated pathway. Eur J Neurosci 7:1220-1228.

Blöchl A, Thoenen H (1996) Localization of cellular storage compartments and sites of constitutive and activity-dependent release of nerve growth factor (NGF) in primary cultures of hippocampal neurons. Mol Cell Neurosci 7:173-190.

Bos JL (1995) A target for phosphoinositide 3-kinase: Akt/PKB. Trends Biochem Sci 20:441-442.

Bozzi Y, Pizzorusso T, Cremisi F, Rossi FM, Barsacchi G, Maffei L (1995) Monocular deprivation decreases the expression of messenger RNA for Brain-Derived Neurotrophic Factor in the rat visual cortex. Neuroscience 69:1133-1144.

Burgin KE, Waxham MN, Rickling S, Westgate SA, Mobley WC, Kelly PT (1990) In situ hybridization histochemistry of $\mathrm{Ca}^{2+} /$ calmodulindependent protein kinase in developing rat brain. $\mathrm{J}$ Neurosci 10:1788-1798.

Burnett PE, Blackshaw S, Lai MM, Qureshi IA, Burnett AF, Sabatini DM, Snyder SH (1998) Neurabin is a synaptic protein linking p70 S6 kinase and the neuronal cytoskeleton. Proc Natl Acad Sci USA 95:8351-8356.

Canossa M, Griesbeck O, Berninger B, Campana G, Kolbeck R, Thoenen H (1997) Neurotrophin release by neurotrophins: implications for activity-dependent neuronal plasticity. Proc Natl Acad Sci USA 94:13279-13286.

Carmignoto G, Pizzorusso T, Tia S, Vicini S (1997) Brain-derived neurotrophic factor and nerve growth factor potentiate excitatory synaptic transmission in the rat visual cortex. J Physiol (Lond) 498:153-164.

Carson JH, Kwon S, Barbarese E (1998) RNA trafficking in myelinating cells. Curr Opin Neurobiol 8:607-612.

Chamow SM, Ashkenazi A (1996) Immunoadhesins: principles and applications. Trends Biotechnol 14:52-60.

Chicurel ME, Terrian DM, Potter H (1993) mRNA at the synapse: analysis of a synaptosomal preparation enriched in hippocampal dendritic spines. J Neurosci 13:4054-4063.

Chicurel ME, Singer RH, Meyer CJ, Ingber DE (1998) Integrin binding and mechanical tension induce movement of mRNA and ribosomes to focal adhesions. Nature 392:730-733.

Coffer PJ, Jin J, Woodgett JR (1998) Protein kinase B (c-Akt): a multifunctional mediator of phosphatidylinositol 3-kinase activation. Biochem J 335:1-13.

Corvera S, Czech MP (1998) Direct targets of phosphoinositide 3-kinase products in membrane traffic and signal transduction. Trends Cell Biol 8:442-446.

Crino PB, Eberwine J (1996) Molecular characterization of the dendritic growth cone: regulated mRNA transport and local protein synthesis. Neuron 17:1173-1187.

Crino P, Khodakhah K, Becker K, Ginsberg S, Hemby S, Eberwine J (1998) Presence and phosphorylation of transcription factors in developing dendrites. Proc Natl Acad Sci USA 95:2313-2318.

Dechant G, Rodriguez-Tebar A, Barde YA (1994) Neurotrophin receptors. Prog Neurobiol 49:53-71.

Deisseroth K, Bito H, Tsien RW (1996) Signaling from synapse to nucleus: postsynaptic CREB phosphorylation during multiple forms of hippocampal synaptic plasticity. Neuron 16:89-101.

D’Mello SR, Borodezt K, Soltoff SP (1997) Insulin-like growth factor and potassium depolarization maintain neuronal survival by distinct pathways: possible involvement of PI 3-kinase in IGF-1 signaling. J Neurosci 17:1548-1560.
Downward J (1995) Signal transduction. A target for PI(3) kinase. Nature 376:553-554.

Downward J (1998) Mechanisms and consequences of activation of protein kinase B/Akt. Curr Opin Cell Biol 10:262-267.

Dudley DT, Pang L, Decker SJ, Bridges AJ, Saltiel AR (1995) A synthetic inhibitor of the mitogen-activated protein kinase cascade. Proc Natl Acad Sci USA 92:7686-7689.

Dugich-Djordjevic MM, Tocco G, Willoughby DA, Najm I, Pasinetti G, Thompson RF, Baudry M, Lapchak PA, Hefti F (1992) BDNF mRNA expression in the developing rat brain following kainic acid-induced seizure activity. Neuron 8:1127-1138.

Frey U, Morris RG (1998) Synaptic tagging: implications for late maintenance of hippocampal long-term potentiation. Trends Neurosci 21:181-188.

Furuichi T, Samon-Chazottes D, Fujino I, Yamada N, Hasegawa M, Miyawaki A, Yoshikawa S, Guenet JL, Mikoshiba K (1993) Widespread expression of inositol 1,4,5-triphosphate receptor type 1 gene (Insp3r1) in the mouse central nervous system. Receptors Channels $1: 11-24$.

Garner CC, Tucker RP, Matus A (1988) Selective localization of messenger RNA for cytoskeletal protein MAP2 in dendrites. Nature 336:674-677.

Gazzaley AH, Benson DL, Huntley GW, Morrison JH (1997) Differential subcellular regulation of NMDAR1 protein and mRNA in dendrites of dentate gyrus granule cells after perforant path transection. J Neurosci 17:2006-2017.

Goodman LJ, Valverde J, Lim F, Geschwind MD, Federhoff HJ, Geller AI, Hefti F (1996) Regulated release and polarized localization of brain-derived neurotrophic factor in hippocampal neurons. Mol Cell Neurosci 7:222-238.

Gottschalk WA, Jiang H, Tartaglia N, Feng L, Figurov A, Lu B (1999) Signaling mechanisms mediating BDNF modulation of synaptic plasticity in the hippocampus. Learn Mem 6:243-256.

Greene LA, Tischler AS (1976) Establishment of noradrenergic clonal line of rat adrenal phaeochromocytoma cells which respond to NGF. Proc Natl Acad Sci USA 73:2424-2428.

Hamers-Casterman C, Atarhouch T, Muyldermans S, Robinson G, Hamers C, Songa EB, Bendahman N, Hamers R (1993) Naturally occurring antibodies devoid of light chains. Nature 363:446-448.

Herb A, Wisden W, Catania MV, Marechal D, Dresse A, Seeburg PH (1997) Prominent dendritic localization in forebrain neurons of a novel mRNA and its product, dendrin. Mol Cell Neurosci 8:367-374.

Kafitz KW, Rose CR, Thoenen H, Konnerth A (1999) Neurotrophinevoked rapid excitation through TrkB receptors. Nature 401:918-921.

Kang H, Schuman EM (1996) A requirement for local protein synthesis in neurotrophin-induced hippocampal synaptic plasticity. Science 273:1402-1406.

Kang H, Welcher AA, Shelton D, Schuman EM (1997) Neurotrophins and time: different roles for TrkB signaling in hippocampal long-term potentiation. Neuron 19:653-664.

Kimura K, Hattori S, Kabuyama Y, Shizawa Y, Takayanagi J, Nakamura S, Toki S, Matsuda Y, Onodera K, Fukui Y (1994) Neurite outgrowth of PC12 cells is suppressed by wortmannin, a specific inhibitor of phosphatidylinositol 3-kinase. J Biol Chem 269:18961-18967.

Knowles RB, Kosik KS (1997) Neurotrophin-3 signals redistribute RNA in neurons. Proc Natl Acad Sci USA 94:14804-14808.

Kokaia Z, Bengzon J, Metsis M, Kokaia M, Persson H, Lindvall O (1993) Coexpression of neurotrophins and their receptors in neurons of the central nervous system. Proc Natl Acad Sci USA 90:6711-6715.

Korte M, Carroll P, Wolf E, Brem G, Thoenen H, Bonhoeffer T (1995) Hippocampal long-term potentiation is impaired in mice lacking brainderived neurotrophic factor. Proc Natl Acad Sci USA 92:8856-8860.

Korte M, Griesbeck O, Gravel C, Carroll P, Staiger V, Thoenen H, Bonhoeffer T (1996) Virus-mediated gene transfer into hippocampal CA1 region restores long-term potentiation in brain-derived neurotrophic factor mutant mice. Proc Natl Acad Sci USA 93:12547-12552.

Kuhl D, Skehel P (1998) Dendritic localization of mRNAs. Curr Opin Neurobiol 8:600-606.

Landry CF, Watson JB, Kashima T, Campagnoni A (1994) Cellular influences on RNA sorting in neurons and glia: an in situ hybridization histochemical study. Mol Brain Res 27:1-11.

Lauterborn JC, Rivera S, Stinis CT, Hayes VY, Isackson PJ, Gall CM (1996) Differential effects of protein synthesis inhibition on the activity-dependent expression of BDNF transcripts: evidence for 
immediate-early gene responses from specific promoters. J Neurosci 16:7428-7436.

Lessmann V, Gottmann K, Heumann R (1994) BDNF and NT-4/5 enhance glutamatergic synaptic transmission in cultured hippocampal neurones. NeuroReport 6:21-25.

Lewin GR, Barde YA (1996) Physiology of the neurotrophins. Annu Rev Neurosci 19:289-317.

Li YX, Zhang Y, Lester HA, Schuman EM, Davidson N (1998) Enhancement of neurotransmitter release induced by brain-derived neurotrophic factor in cultured hippocampal neurons. J Neurosci 18:10231-10240.

Link W, Konietzko U, Kauselmann G, Krug M, Schwanke B, Frey U, Kuhl D (1995) Somatodendritic expression of an immediate early gene is regulated by synaptic activity. Proc Natl Acad Sci USA 92:5734-5738.

Lohof AM, Ip NY, Poo MM (1993) Potentiation of developing neuromuscular synapses by the neurotrophins NT-3 and BDNF. Nature 363:350-353.

Lyford GL, Yamagata K, Kaufmann WE, Barnes CA, Sanders LK, Copeland NG, Gilbert DJ, Jenkins NA, Lanahan AA, Worley PF (1995) Arc, a growth factor and activity-regulated gene, encodes a novel cytoskeleton-associated protein that is enriched in neuronal dendrites. Neuron 14:433-445.

Maisonpierre PC, Le Beau MM, Espinosa R3d, Ip NY, Belluscio L, de la Monte SM, Squinto S, Furth ME, Yancopulos GD (1991) Human and rat brain-derived neurotrophic factor and neurotrophin-3: gene structures, distributions and chromosomal localizations. Genomics 10:558-568.

Malgaroli A, Tsien RW (1992) Glutamate-induced long-term potentiation of the frequency of miniature synaptic currents in cultured hippocampal neurons. Nature 357:134-139.

Middlemas DS, Lindberg RA, Hunter T (1991) TrkB, a neural receptor protein-tyrosine kinase: evidence for a full-length and two truncated receptors. Mol Cell Biol 11:143-153.

Miranda RC, Sohrabji F, Toran-Allerand CD (1993) Neuronal colocalization of mRNAs for neurotrophins and their receptors in the developing central nervous system suggests a potential for autocrine interactions. Proc Natl Acad Sci USA 90:6439-6443.

Morris BJ (1997) Stabilization of dendritic mRNAs by nitric oxide allows localized, activity-dependent enhancement of hippocampal protein synthesis. Eur J Neurosci 9:2334-2339.

Ouyang Y, Rosenstein A, Kreiman G, Schuman EM, Kennedy MB (1999) tetanic stimulation leads to increased accumulation of Ca2+/ calmodulin-dependent protein kinase II via dendritic protein synthesis in hippocampal neurons. J Neurosci 19:7823-7833.

Patterson SL, Abel T, Deuel TA, Martin KC, Rose JC, Kandel ER (1996) Recombinant BDNF rescues deficits in basal synaptic transmission and hippocampal LTP in BDNF knockout mice. Neuron 16:1137-1145.

Plopper GE, McNamee HP, Dike LE, Bojanowski K, Ingber DE (1995) Convergence of integrin and growth factor receptor signaling pathways within the focal adhesion complex. Mol Biol Cell 6:1349-1365.

Polakiewicz RD, Schieferl SM, Gingras AC, Sonenberg N, Comb MJ (1998) $\mu$-Opioid receptor activates signaling pathways implicated in cell survival and translational control. J Biol Chem 273:23534-23541.

Prakash N, Fehr S, Mohr E, Richter D (1997) Dendritic localization of rat vasopressin mRNA: ultrastructural analysis and mapping of targeting elements. Eur J Neurosci 9:523-532.

Racca C, Gardiol A, Triller A (1997) Dendritic and postsynaptic localizations of glycine receptor alpha subunit mRNAs. J Neurosci 17:1691-1700.

Roberts LA, Large CH, Higgins MJ, Stone TW, O'Shaughnessy CT, Morris BJ (1998) Increased expression of dendritic mRNA following the induction of long-term potentiation. Mol Brain Res 56:38-44.
Schmidt-Kastner R, Humpel C, Wetmore C, Olson L (1996) Cellular hybridization for BDNF, trkB, and NGF mRNAs and BDNFimmunoreactivity in rat forebrain after pilocarpine-induced status epilepticus. Exp Brain Res 107:331-347.

Schuman EM (1997) Synapse specificity and long-term information storage. Neuron 18:339-342.

Schuman EM (1999) Neurotrophin regulation of synaptic transmission. Curr Opin Neurobiol 9:105-109.

Solem M, McMahon T, Messing RO (1995) Depolarization-induced neurite outgrowth in PC12 cells requires permissive, low level NGF receptor stimulation and activation of calcium/calmodulin-dependent protein kinase. J Neurosci 15:5966-5975.

Steward O (1997) mRNA localization in neurons: a multipurpose mechanism? Neuron 18:9-12.

Steward O, Halpain S (1999) Lamina-specific synaptic activation causes domain-specific alterations in dendritic immunostaining for MAP2 and CAM kinase II. J Neurosci 19:7834-7845.

Steward O, Wallace CS, Lyford GL, Worley PF (1998) Synaptic activation causes the mRNA for the IEG Arc to localize selectively near activated postsynaptic sites on dendrites. Neuron 21:741-751.

Thoenen H (1995) Neurotrophins and neuronal plasticity. Science 270:593-598.

Tiedge H, Bloom FE, Richter D (1999) RNA, whither goest thou? Science 283:186-187.

Tokumitsu H, Chijiwa T, Hagiwara M, Mizutani A, Terasawa M, Hidaka $\mathrm{H}$ (1990) KN-62, 1-[N,O-bis(5-isoquinolinesulfonyl)- $N$-methyl-Ltyrosyl]-4-phenylpiperazine, a specific inhibitor of $\mathrm{Ca}^{2+} /$ calmodulindependent protein kinase II. J Biol Chem 265:4315-4320.

Tongiorgi E, Righi M, Cattaneo A (1997) Activity-dependent dendritic targeting of BDNF and TrkB mRNAs in hippocampal neurons. J Neurosci 17:9492-9505.

Tongiorgi E, Righi M, Cattaneo A (1998) A non-radioactive in situ hybridization method that does not require RNAse-free conditions. J Neurosci Methods 85:129-139.

Tongiorgi E, Armellin M, Giulianini PG, Ferrero EA, Cattaneo A (1999) Pilocarpine seizures induce extensive dendritic localization of BDNF mRNA in subiculum and CA1 hippocampal neurons in vivo. Soc Neurosci Abstr 25:1785.

Torre ER, Steward O (1992) Demonstration of local protein synthesis within dendrites using a new cell culture system that permits the isolation of living axons and dendrites from their cell bodies. J Neurosci 12:762-772.

Yan Q, Rosenfeld RD, Matheson CR, Hawkins N, Lopez OT, Bennett L, Welcher AA (1997) Expression of brain-derived neurotrophic factor protein in the adult rat central nervous system. Neuroscience 78:431-448.

Ui M, Okada T, Hazeki K, Hazeki O (1995) Wortmannin as a unique probe for an intracellular signalling protein, phosphoinositide 3-kinase. Trends Biochem Sci 20:303-307.

Vanhaesebroeck B, Jones GE, Allen WE, Zicha D, Hooshmand-Rad R, Sawyer C, Wells C, Waterfield MD, Ridley AJ (1999) Distinct $\mathrm{PI}(3) \mathrm{Ks}$ mediate mitogenic signalling and cell migration in macrophages. Nat Cell Biol 1:69-71.

Zafra F, Hengerer B, Leibrock J, Thoenen H, Lindholm D (1990) Activity dependent regulation of BDNF and NGF mRNAs in the rat hippocampus is mediated by non-NMDA glutamate receptors. EMBO J 9:3545-3550.

Zafra F, Lindholm D, Castren E, Hatikka J, Thoenen H (1992) Regulation of brain-derived neurotrophic factor and nerve growth factor mRNA in primary cultures of hippocampal neurons and astrocytes. J Neurosci 12:4793-4799. 